\title{
Raloxifene acutely suppresses ventricular myocyte contractility through inhibition of the L-type calcium current
}

\author{
${ }^{1}$ Reginald Liew, ${ }^{2}$ Mark A. Stagg, *,1 Kenneth T. MacLeod \& ${ }^{1}$ Peter Collins \\ ${ }^{1}$ Cardiac Medicine, National Heart and Lung Institute, Imperial College London, Dovehouse Street, London, SW3 6LY and \\ ${ }^{2}$ Heart Science Centre, National Heart and Lung Institute, Harefield Hospital, Harefield, Middlesex, UB9 6JH
}

1 The selective oestrogen (ER) receptor modulator, raloxifene, is widely used in the treatment of postmenopausal osteoporosis, but may also possess cardioprotective properties. We investigated whether it directly suppresses myocyte contractility through $\mathrm{Ca}^{2+}$ channel antagonism in a similar way to $17 \beta$-oestradiol.

2 Cell shortening and $\mathrm{Ca}^{2+}$ transients were measured in single guinea-pig ventricular myocytes fieldstimulated $\left(1 \mathrm{~Hz}, 37^{\circ} \mathrm{C}\right)$ in a superfusion chamber. Electrophysiological recordings were performed using single electrode voltage-clamp.

3 Raloxifene decreased cell shortening $\left(\mathrm{EC}_{50} 2.4 \mu \mathrm{M}\right)$ and the $\mathrm{Ca}^{2+}$ transient amplitude $\left(\mathrm{EC}_{50} 6.4 \mu \mathrm{M}\right)$ in a concentration-dependent manner. At a concentration of $1 \mu \mathrm{M}$, raloxifene produced a $33 \pm 2 \%$ (mean \pm s.e.m) and $24 \pm 2 \%$ reduction, respectively $(P<0.001, n=14$ for both parameters).

4 These inhibitory actions were not observed in myocytes that had been incubated with the specific antagonist, ICI 182,780 $(10 \mu \mathrm{M})(n=11)$.

5 Raloxifene $(1 \mu \mathrm{M})$ shortened action potential durations at 50 and $90 \%$ repolarisation $(P<0.05$ and $<0.001$, respectively; $n=27)$ and decreased peak L-type $\mathrm{Ca}^{2+}$ current by $45 \%$, from $-5.1 \pm 0.5 \mathrm{pA} / \mathrm{pF}$ to $-2.8 \pm 0.3 \mathrm{pA} / \mathrm{pF}(P<0.001, n=18)$.

6 Raloxifene did not significantly alter sarcoplasmic reticulum $\mathrm{Ca}^{2+}$ content, as assessed by integrating the $\mathrm{Na}^{+} / \mathrm{Ca}^{2+}$ exchanger currents following rapid caffeine application.

7 The present study provides evidence for direct inhibitory actions of raloxifene on ventricular myocyte contractility, mediated through $\mathrm{Ca}^{2+}$ channel antagonism.

British Journal of Pharmacology (2004) 142, 89-96. doi:10.1038/sj.bjp.0705736

Keywords: Raloxifene; selective oestrogen receptor modulator; SERM; $\mathrm{Ca}^{2+}$ channel; calcium; excitation contraction coupling; EC coupling; cardiac myocyte; sarcoplasmic reticulum; action potential; ICI 182,780

Abbreviations: APD, action potential duration; DMSO, dimethyl sulphoxide; EGTA, 1, 2-di(2-aminoethoxy)ethane- $N N N^{\prime} N^{\prime}$ tetra-acetic acid; HEPES, $N$-2-hydroxyethylpiperazine- $N^{\prime}$-2- ethanesulphonic acid; $\mathrm{I}_{\mathrm{Ca}, \mathrm{L}}$, L-type calcium channel; ER, oestrogen receptor

\section{Introduction}

Cardiovascular disease is a major cause of death among postmenopausal women in the Western world (Mosca et al., 1997). Although observational studies have suggested that hormone replacement therapy may be cardioprotective (Wenger et al., 1993; Hayward et al., 2000), recent large trials using oral conjugated oestrogens and medroxyprogesterone acetate have not confirmed this (Grady et al., 2002). Consequently, there has been increasing interest in the use of alternative postmenopausal agents, which possess the benefits of traditional hormone replacement therapy while also being cardioprotective. Raloxifene, widely used in the treatment and prevention of postmenopausal osteoporosis, may be such an agent (Riggs \& Hartmann, 2003). Being a selective oestrogen receptor (ER) modulator, it can act as an agonist or antagonist at the ER, depending on the target tissue (Dardes \& Jordan, 2000; Lonard \& Smith, 2002; Riggs \& Hartmann, 2003). It therefore has the potential to exert beneficial oestrogenic effects on the cardio-

*Author for correspondence; E-mail: k.t.macleod@imperial.ac.uk Advance online publication: 15 March 2004 vascular system and bone, without producing harmful effects on the uterus and mammary glands (Delmas et al., 1997).

The potential mechanisms through which raloxifene may afford cardioprotection are poorly understood and are likely to involve direct as well as indirect actions, such as favourable changes in the lipid profile (Walsh et al., 1998). Animal studies investigating the effects of raloxifene on atherosclerosis have produced contradictory results (Bjarnason et al., 1997; Clarkson et al., 1998), while studies investigating the direct vascular actions of raloxifene have demonstrated beneficial effects. For example, raloxifene has been shown to exert acute, nongenomic, ER-mediated actions on rabbit coronary arteries and human umbilical vein endothelial cells through rapid activation of nitric oxide synthase (Figtree et al., 1999; Simoncini et al., 2002). In addition, raloxifene improves endothelial dysfunction and reduces blood pressure in spontaneously hypertensive male rats (Wassmann et al., 2002). Few studies have addressed the issue as to whether raloxifene exerts any direct actions on the heart. The finding that raloxifene reduces myocardial ischaemia-reperfusion injury in the canine heart is similar to that observed with the mammalian oestrogen, $17 \beta$-oestradiol, and highlights the 
similarities in myocardial action between these two compounds (Jovanovic et al., 2000; Zhai et al., 2000; Ogita et al., 2002).

It has long been known that $17 \beta$-oestradiol can exert direct actions on the heart through inhibition of the L-type calcium current $\left(\mathrm{I}_{\mathrm{Ca}, \mathrm{L}}\right)$, although these effects have tended to occur at supra-physiological concentrations (Jiang et al., 1992; Meyer et al., 1998). In the present study, we tested the hypothesis that raloxifene acts as a $\mathrm{Ca}^{2+}$ channel antagonist on the heart and suppresses ventricular myocyte contractility in a similar way to $17 \beta$-oestradiol. We report on novel direct cardiac actions of raloxifene that appear to be mediated via the ER and which result in decreased cell shortening.

\section{Methods}

\section{Cell isolation and indo-1 loading}

Experiments were performed on single left ventricular myocytes isolated from adult male guinea pigs $(550-750 \mathrm{~g})$ by enzymatic digestion as previously described (MacLeod \& Harding, 1991). We chose to study male, rather than female, animals to avoid the potential problems associated with varying expression of the ER that occurs throughout the oestrus cycle. Myocytes were stored in Dulbecco's modified Eagle's medium solution at room temperature and loaded with $10 \mu \mathrm{M}$ of the acetoxymethyl ester form of the $\mathrm{Ca}^{2+}$-sensitive fluorescent dye, indo-1 (Molecular Probes, Eugene, OR, U.S.A.) for $25 \mathrm{~min}$. Once loaded, cells were not used for at least another $30 \mathrm{~min}$ to allow the intracellular indo-1-AM to be de-esterified. The investigation conformed with the Guide for the Care and Use of Laboratory Animals published by the US National Institutes of Health (NIH Publication No. 85-23, revised 1996).

\section{Cell shortening and intracellular $\mathrm{Ca}^{2+}$ measurements}

Cells were superfused with normal Tyrode, NT (containing in mM: $\mathrm{NaCl} 140, \mathrm{KCl} 6, \mathrm{CaCl}_{2} 2, \mathrm{MgCl}_{2} 1$, glucose $10, \mathrm{~N}-2-$ hydroxyethylpiperazine- $N^{\prime \prime}$-2- ethanesulphonic acid (HEPES) $10, \mathrm{pH}$ adjusted to 7.4. using $\mathrm{NaOH}$ ) in a low volume chamber mounted on the stage of an inverted microscope. Two platinum electrodes, placed on either side of the chamber, were used to field stimulate the myocytes at a rate of $1 \mathrm{~Hz}$. Myocytes were directly visualised using a $\times 40$ oil immersion objective (Nikon) and a single rod shaped cell with clear striations, clean edges and good contractions when stimulated was chosen. Cell shortening was monitored at one end with a video edge-detector system and the indo-1 fluorescence emission ratio (i.e. ratio of light emitted at wavelengths 405 and $485 \mathrm{~nm}$ ) was simultaneously recorded using a pair of photomultiplier tubes.

Once steady-state contractions were achieved, raloxifene (or $17 \beta$-oestradiol) was added to the superfusate and the new steady-state contractions and indo-1 ratio were recorded. Experiments were tightly paired so that changes in cell shortening and the indo- 1 ratio, $\Delta$ indo- 1 ratio (i.e. peak minus resting indo-1 ratios), before and after the addition of raloxifene could be compared. This allowed the $\Delta$ indo- 1 ratio during field stimulation to be used as a qualitative measure of the effects of raloxifene, on the $\mathrm{Ca}^{2+}$ transient, even though the relationship between the indo- 1 ratio and intracellular-free $\mathrm{Ca}^{2+}$ concentration is not linear. In addition, use of actual indo-1 ratios, rather than calculated $\mathrm{Ca}^{2+}$ concentrations, avoided the potential errors that can result from dye compartmentalisation during calibration experiments (Spurgeon et al., 1990).

All experiments were performed at $37^{\circ} \mathrm{C}$ and each bath of cells was changed following every exposure to raloxifene in order to avoid residual effects of incomplete washout of the drug.

\section{Effects of ICI 182,780}

The specific ER antagonist ICI 182,780 (Tocris, UK) was used to investigate whether the effects of raloxifene on cell shortening and the $\mathrm{Ca}^{2+}$ transient were mediated via the ER. Indo-1 loaded myocytes were incubated with $10 \mu \mathrm{M} \mathrm{ICI}$ 182,780 at room temperature for $1 \mathrm{~h}$ before being placed in the superfusion chamber. Cell shortening and the indo-1 ratio were measured in the continuing presence of $10 \mu \mathrm{M}$ ICI 182,780 before and after the addition of $1 \mu \mathrm{M}$ raloxifene. The concentration of ICI 182,780 chosen $(10 \mu \mathrm{M})$ has previously been shown to be effective in inhibiting the acute relaxing effects of raloxifene on coronary arteries (Figtree et al., 1999).

\section{Electrophysiology}

Electrophysiological parameters were measured in control solution and then in the presence of $1 \mu \mathrm{M}$ raloxifene using an Axoclamp-2B system and pCLAMP software (Axon Instruments, Foster City, CA, U.S.A.). Action potentials were elicited under current-clamp using $1 \mathrm{nA}$ pulses $(5$ or $10 \mathrm{~ms}$ duration at $1 \mathrm{~Hz}$ ) and action potential durations at 50 and $90 \%$ repolarisation $\left(\mathrm{APD}_{50}\right.$ and $\mathrm{APD}_{90}$, respectively) were determined. $\mathrm{I}_{\mathrm{Ca}, \mathrm{L}}$ was recorded under voltage-clamp (discontinuous switch mode with the switching rate set between 4 and $6 \mathrm{kHz}$ ) using a holding potential of $-40 \mathrm{mV}$. Care was taken to monitor the switching period to avoid false-clamp and optimise clamp speed. Test pulses of $200 \mathrm{~ms}$ duration, ranging from -45 to $+50 \mathrm{mV}$, were imposed and $\mathrm{I}_{\mathrm{Ca}, \mathrm{L}}$ determined by subtracting the current obtained during cadmium application $(100 \mu \mathrm{M})$ from the one elicited before cadmium application. High-resistance microelectrodes were used to limit dialysis of the cells. These were pulled from borosilicate glass (Clark Electromedical Instruments, Reading, U.K.) and had resistances between 20 and $30 \mathrm{M} \Omega$ when filled with solution containing: $\mathrm{KCl} 2 \mathrm{M}$; 1,2-di(2-aminoethoxy)ethane- $N N N^{\prime} N^{\prime}$ tetra-acetic acid (EGTA), 0.1 mM; HEPES, $5 \mathrm{mM}$, pH 7.2.

Steady-state activation parameters of $\mathrm{I}_{\mathrm{Ca}, \mathrm{L}}$ were obtained from the relationship between membrane conductance and the imposed potential. Steady-state inactivation parameters were analysed with double-pulse protocols. Conditioning pulses ( $200 \mathrm{~ms}$ duration) ranging from -55 to $+50 \mathrm{mV}$ were imposed from a holding potential of $-50 \mathrm{mV}$. At $5 \mathrm{~ms}$ after the end of each conditioning pulse, a test pulse to $+5 \mathrm{mV}(200 \mathrm{~ms}$ duration) was applied to elicit the $\mathrm{Ca}^{2+}$ current.

Sarcoplasmic reticulum $\mathrm{Ca}^{2+}$ load was measured using rapid application of caffeine and integrating the resulting inward $\mathrm{Na}^{+} / \mathrm{Ca}^{2+}$ exchanger current (Varro et al., 1993). Myocytes were voltage-clamped at $-80 \mathrm{mV}$ and subjected to a train of 10 prepulses to $+30 \mathrm{mV}$. In total $10 \mathrm{~ms}$ after the last pre-pulse, $10 \mathrm{mM}$ caffeine was rapidly applied to the superfusing solution to produce a sudden release of $\mathrm{Ca}^{2+}$ from the sarcoplasmic reticulum and elicit the $\mathrm{Na}^{+} / \mathrm{Ca}^{2+}$ exchanger 
current. Caffeine application was maintained for $6 \mathrm{~s}$ to prevent sarcoplasmic reticular $\mathrm{Ca}^{2+}$ resequestration, and thereby ensure that the $\mathrm{Na}^{+} / \mathrm{Ca}^{2+}$ exchanger essentially removed all the $\mathrm{Ca}^{2+}$ released from the sarcoplasmic reticulum.

\section{Drugs}

Raloxifene hydrochloride (LY 139481) was a gift from Eli Lilly (Indianapolis, IN, U.S.A.). $17 \beta$-oestradiol was purchased from Sigma-Aldrich, U.K. All drugs were analytical grade and dissolved in dimethyl sulphoxide (DMSO) to make a $100 \mathrm{mM}$ stock solution. The maximum final concentration of DMSO used $(0.05 \%)$ had no significant effect on cell shortening or the $\Delta$ indo- 1 ratio (parameters in NT with $0.05 \%$ DMSO measured $103.4 \pm 4.1$ and $96.4 \pm 2.9 \%$, respectively, compared with equivalent parameter in NT alone; $P=$ nonsignificant using paired $t$-test, $n=7$ ).

\section{Statistical Analysis and curve fitting}

Results are expressed as mean \pm s.e.m and analysed using the Student's $t$-test, repeated measures or one-way ANOVA with Bonferroni post-test as appropriate. A value of $P<0.05$ was considered significant.

The concentration - response relationships of raloxifene and the percentage inhibition of cell shortening and the $\Delta$ indo- 1 ratio were analysed by nonlinear regression (GraphPad Prism software, San Diego, CA, U.S.A.) using a modified Hill equation

$$
Y=Y_{\min }+\left[\frac{\left(Y_{\max }-Y_{\min }\right)}{1+10^{\left(\operatorname{LogEC}_{50}-\log \mathrm{X}\right) H}}\right]
$$

where $Y$ is the response (percentage inhibition of cell shortening or the $\Delta$ indo- 1 ratio) to a particular concentration of raloxifene, $X$. The minimum inhibition $\left(Y_{\min }\right)$ is the percentage change with raloxifene at which there was no significant difference from baseline values in NT and the maximum inhibition $\left(Y_{\max }\right)$ is taken as $100 \%$. This allowed the $\mathrm{EC}_{50}$ (raloxifene concentration producing 50\% inhibition) and Hill coefficient $(H)$ to be determined.

The relationships between membrane potentials and $\mathrm{Ca}^{2+}$ channel activation or inactivation were fitted with the Boltzmann function:

$$
G=G_{\min }+\frac{\left(G_{\max }-G_{\min }\right)}{1+\exp \left(\frac{V_{50}-X}{K}\right)}
$$

where $G$ is the conductance at membrane potential $X, G_{\min }$ and $G_{\max }$ are the minimum and maximum conductances respectively and $K$ is the slope factor. This allowed the membrane potential, $V_{50}$, when half the channels are activated $\left(d_{\infty}\right.$ variable) or inactivated ( $f_{\infty}$ variable) to be determined in the presence and absence of raloxifene.

\section{Results}

\section{Effects of raloxifene on cell shortening and the $\mathrm{Ca}^{2+}$ transient}

Raloxifene inhibited cell shortening and the $\Delta$ indo- 1 ratio during field stimulation in a concentration-dependent manner (Figure 1). The $\mathrm{EC}_{50}$ of raloxifene effect on cell shortening and the $\Delta$ indo- 1 ratio were $2.4 \mu \mathrm{M}$ and $6.4 \mu \mathrm{M}$, respectively, with corresponding $H$ values of 0.75 and 0.71 . A concentration of $1 \mu \mathrm{M}$ raloxifene (similar to the $\mathrm{EC}_{50}$ for cell shortening) was subsequently used for the majority of the following experiments. Representative recordings showing the acute actions of $1 \mu \mathrm{M}$ raloxifene on cell shortening and the $\Delta$ indo- 1 ratio are shown in Figure 1.

Similar experiments on field stimulated myocytes were performed with $17 \beta$-oestradiol in order to compare the acute actions of the two oestrogenic compounds. As the acute cardiac actions of $17 \beta$-oestradiol have previously been demonstrated to occur at supra-physiological concentrations (Jiang et al., 1992; Meyer et al., 1998), we chose to use a concentration of $40 \mu \mathrm{M}$ in these experiments. Both raloxifene and $17 \beta$-oestradiol significantly decreased cell shortening and the $\Delta$ indo-1 ratio (Figure 2). However, the speed of action of raloxifene appeared to be slower than that of $17 \beta$-oestradiol, as can be seen in the continuous traces. The effect of $40 \mu \mathrm{M}$ raloxifene on cell shortening was irreversible, in contrast to that of $17 \beta$-oestradiol, which was quickly reversed upon washout with control solution.

\section{Effects after myocyte incubation with ICI 182,780}

We next investigated whether the inhibitory actions of raloxifene on myocyte contractility were mediated through
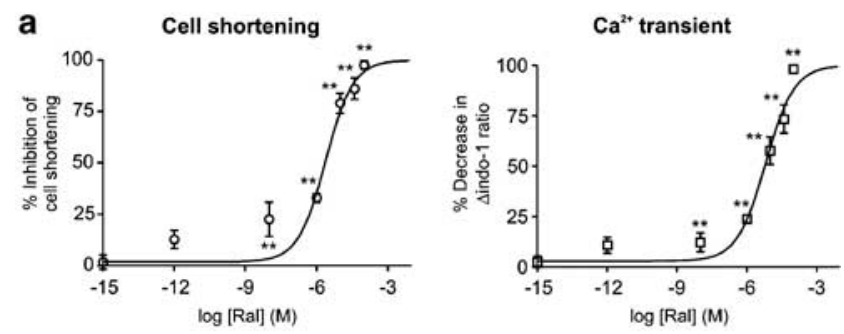

b
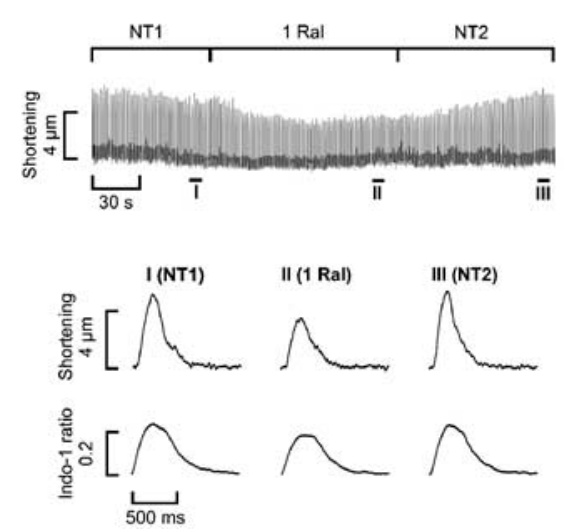

Figure 1 Acute effects of raloxifene on cell shortening and the $\mathrm{Ca}^{2+}$ transient. (a) Concentration-response curves: parameters are expressed as a percentage decrease (mean \pm s.e.m) relative to the initial value in control solution. Sigmoidal curves have been fitted using nonlinear regression, giving $\mathrm{EC}_{50}$ values of $2.4 \mu \mathrm{M}$ for cell shortening and $6.4 \mu \mathrm{M}$ for the $\mathrm{Ca}^{2+}$ transient $(n=5-14$ cells at each concentration, ${ }^{* *} P<0.01$ ). (b) Continuous recording of cell shortening showing the effect of $1 \mu \mathrm{M}$ raloxifene (1 Ral). NT1 and NT2 are the periods in control solution (normal Tyrode) before and immediately after addition of raloxifene. Magnified averaged traces of six consecutive contractions in parts I-III of the continuous trace plotted at a faster sweep speed showing twitch and $\mathrm{Ca}^{2+}$ transient morphologies. 
a

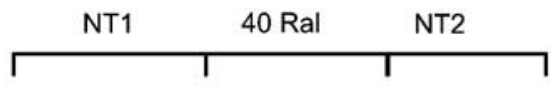
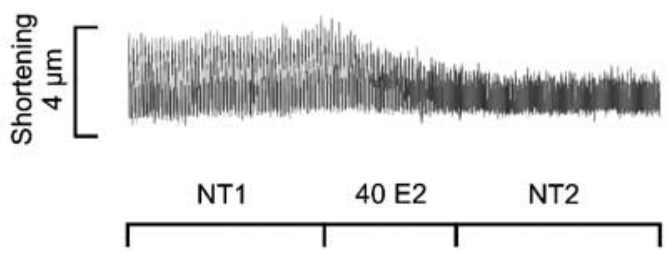

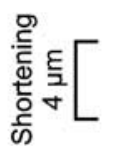

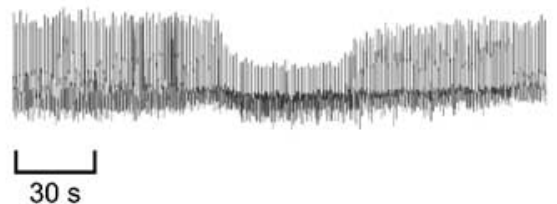

b
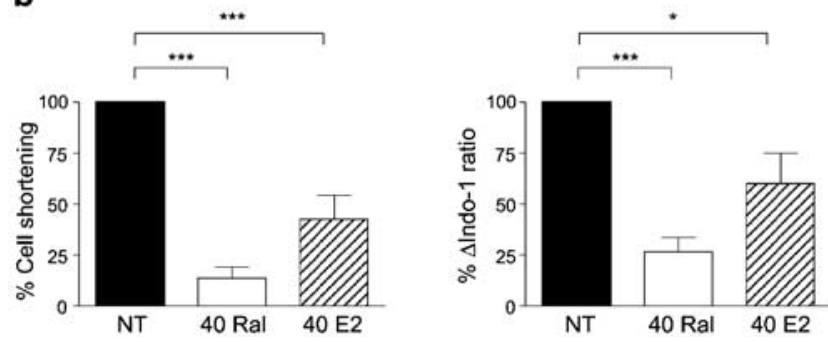

Figure 2 Comparison of raloxifene and $17 \beta$-oestradiol actions on cell shortening and the $\mathrm{Ca}^{2+}$ transient. (a) Representative continuous traces showing the decrease in cell shortening following the addition of $40 \mu \mathrm{M}$ raloxifene (40 Ral) or $17 \beta$-oestradiol (40 E2) to the superfusing solution. NT1 and NT2 are the periods in control solution before and immediately after addition of the oestrogenic compounds, respectively. (b) Bar graphs showing cell shortening and $\Delta$ indo- 1 ratio in the presence of $40 \mu \mathrm{M}$ raloxifene and $17 \beta$-oestradiol, expressed as a percentage of initial values. $(n=5$ in each group, $* P<0.05, * * * P<0.001)$

interactions with the ER using the specific ER antagonist, ICI 182,780. Control experiments were first performed to determine whether $10 \mu \mathrm{M}$ ICI 182,780 had any direct actions of its own on cell contractility. We found that this concentration of the ER antagonist had no significant effects on cell shortening or $\mathrm{Ca}^{2+}$ transient parameters (amplitudes and kinetics) when acutely applied (comparing paired data before and after the addition of ICI $182,780, n=9$ ) or after a $1 \mathrm{~h}$ incubation period (comparing unpaired data between cells incubated with and without ICI $182,780, n=12)$.

Raloxifene $(1 \mu \mathrm{M})$ decreased cell shortening by $33 \pm 2 \%$ and the $\mathrm{Ca}^{2+}$ transient amplitude by $24 \pm 2 \%$ of control values $(P<0.001, n=14$ for both parameters, Figure 3$)$. The suppression of cell shortening was reversible upon washout with NT, but the decrease in $\mathrm{Ca}^{2+}$ transient amplitude was only partially reversible despite an NT washout period in excess of $10 \mathrm{~min}$. Raloxifene significantly decreased both diastolic and systolic indo-1 ratios compared with control values in NT. The decrease in diastolic indo-1 ratio was fully reversible upon washout with NT, whereas the change in systolic ratio was only partially reversible. Myocyte incubation with ICI 182,780 for $1 \mathrm{~h}$ completely abolished the inhibitory actions of raloxifene on cell shortening and the indo-1 ratios, suggesting that these effects were mediated through the ER.

Raloxifene significantly increased the time taken to reach peak $\mathrm{Ca}^{2+}$ transient from $244 \pm 10$ to $293 \pm 14 \mathrm{~ms}(P<0.001$, a
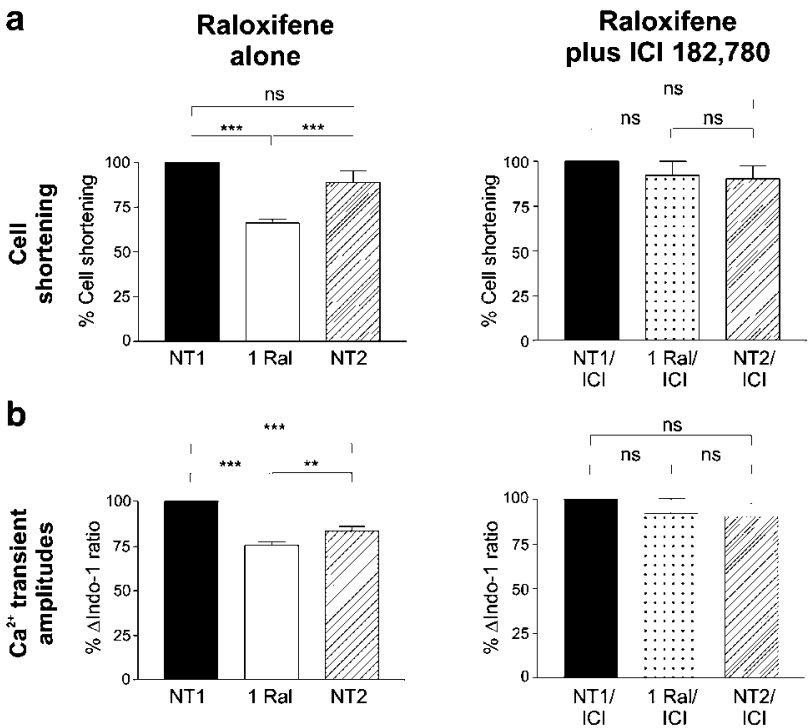

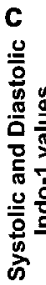
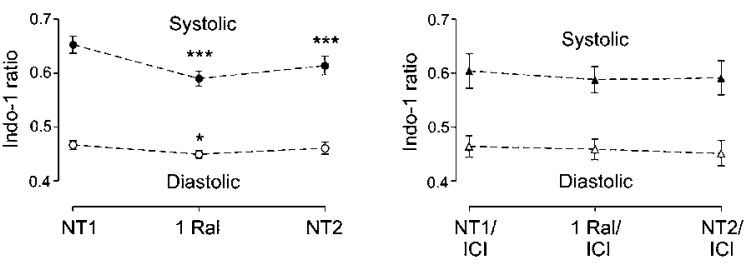

Figure 3 Effects of raloxifene on cell shortening and the indo-1 ratios before (left) and after (right) myocyte incubation with ICI $182,780.1 \mu \mathrm{M}$ raloxifene (1 Ral) decreased cell shortening (a), $\mathrm{Ca}^{2+}$ transient amplitudes (b) and systolic and diastolic indo-1 ratios (c) compared with initial values in control solution (NT1). These effects are no longer present in myocytes that have been preincubated $10 \mu \mathrm{M}$ ICI 182,780 (ICI) for $1 \mathrm{~h}(n=11-14$ in each group, $\mathrm{NS}=$ nonsignificant, $* P<0.05, * * P<0.01, * * * P<0.001)$

$n=14)$. However, this effect on $\mathrm{Ca}^{2+}$ transient kinetics was no longer observed after myocyte incubation with ICI 182,780 (Figure 4). Raloxifene did not significantly alter the time-to$50 \%$ decay of the $\mathrm{Ca}^{2+}$ transient (R50) in the absence or presence of ICI 182,780 .

\section{Raloxifene effects on the action potential profile}

Raloxifene $(1 \mu \mathrm{M})$ did not significantly alter the resting membrane potential, which was $-75 \pm 1 \mathrm{mV}(n=27)$ in both NT and in the presence of raloxifene. Figure 5 illustrates the effects of raloxifene on action potential waveform. Raloxifene decreased $\mathrm{APD}_{50}$ from $235 \pm 23$ to $205 \pm 19 \mathrm{~ms} \quad(P<0.05$, $n=27)$ and $\mathrm{APD}_{90}$ from $300 \pm 23$ to $254 \pm 18 \mathrm{~ms} \quad(P<0.01$, Figure 5). These changes were fully reversible upon washout in NT $(P=$ NS using paired $t$ test between in NT before and after raloxifene addition; $n=9$ ).

\section{Effects of raloxifene on the $\mathrm{Ca}^{2+}$ current}

Raloxifene $(1 \mu \mathrm{M})$ significantly decreased the peak $\mathrm{I}_{\mathrm{Ca}, \mathrm{L}}$ from $-5.1 \pm 0.5$ to $-2.8 \pm 0.3 \mathrm{pA} / \mathrm{pF}(P<0.001, n=18)$, that is, raloxifene inhibited peak $\mathrm{I}_{\mathrm{Ca}, \mathrm{L}}$ by $45 \%$ (Figure 6 ). This inhibition occurred over the range of voltages tested and was only partially reversible upon washout with NT. The raloxifene-induced inhibition of $\mathrm{I}_{\mathrm{Ca}, \mathrm{L}}$ took effect within $1 \mathrm{~min}$ 

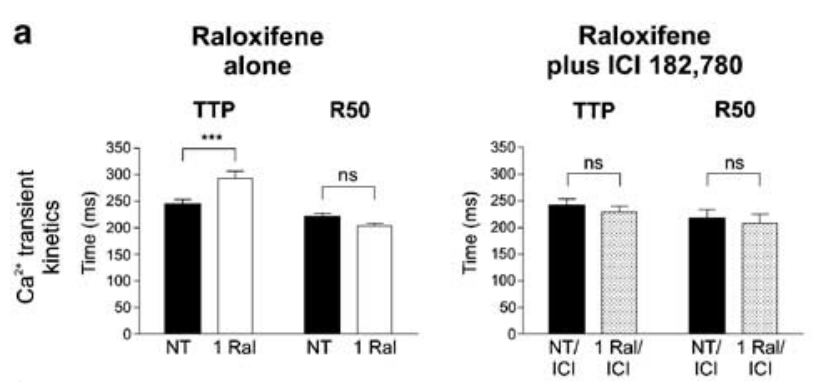

b
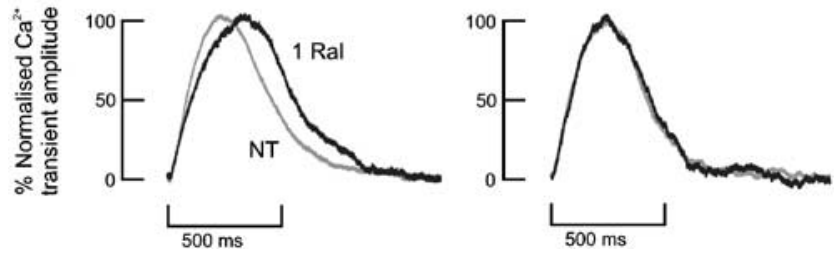

Figure 4 Effects of $1 \mu \mathrm{M}$ raloxifene on $\mathrm{Ca}^{2+}$ transient kinetics. (a) Bar graphs showing the effects of raloxifene (1 Ral) on the time-topeak indo-1 ratio (TTP) and time-to-50\% $\mathrm{Ca}^{2+}$ transient decay (R50) in freshly isolated myocytes (left) and in myocytes that have been preincubated with $10 \mu \mathrm{M}$ ICI 182,780 for $1 \mathrm{~h}$ (right). ( $n=14$, $* * * P<0.001)$. (b) Representative traces of $\mathrm{Ca}^{2+}$ transients in normal tyrode (NT, grey traces) and in the presence of raloxifene (black traces). Traces have been normalised to the same amplitude to facilitate comparison. Raloxifene can be seen to prolong TTP in the myocyte on the left, but not in the myocyte preincubated with ICI 182,780 on the right.

a

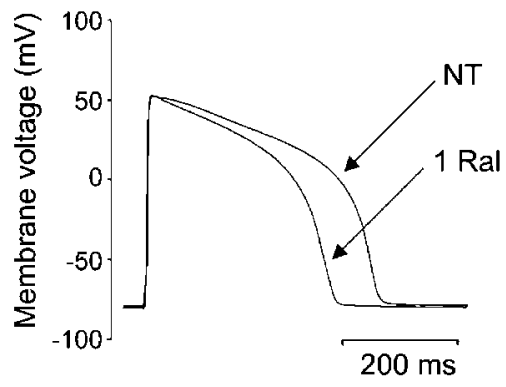

b
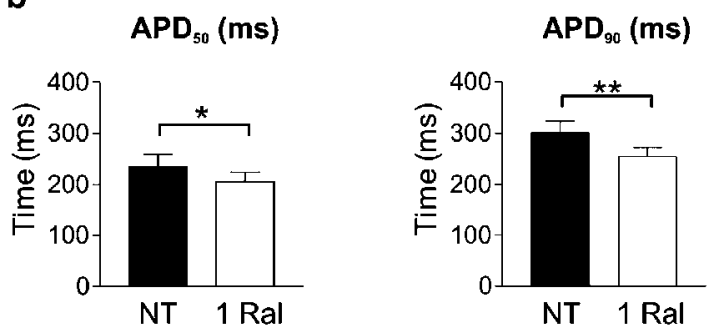

Figure 5 Effects of $1 \mu \mathrm{M}$ raloxifene on action potential duration. (a) Sample recording of the membrane potential during steady-state stimulation at $1 \mathrm{~Hz}$ in normal Tyrode (NT) and in the presence of $1 \mu \mathrm{M}$ Raloxifene (1 Ral). (b) Bar graphs showing significantly shortened times-to- $50 \%$ and $90 \%$ repolarisation of the membrane $\left(\mathrm{APD}_{50}\right.$ and $\mathrm{APD}_{90}$, respectively) in the presence of raloxifene $(n=27, * P<0.05, * * P<0.01)$.

(Figure 7). This could not be attributed to current rundown, which was found to be negligible over this period $(0.0002 \pm 0.0001 \mathrm{pA} / \mathrm{pF} / \mathrm{min}, n=7)$.

Raloxifene did not significantly shift the $\mathrm{Ca}^{2+}$ channel activation or inactivation curves (Figure 8). $\mathrm{V}_{50}$ for activation

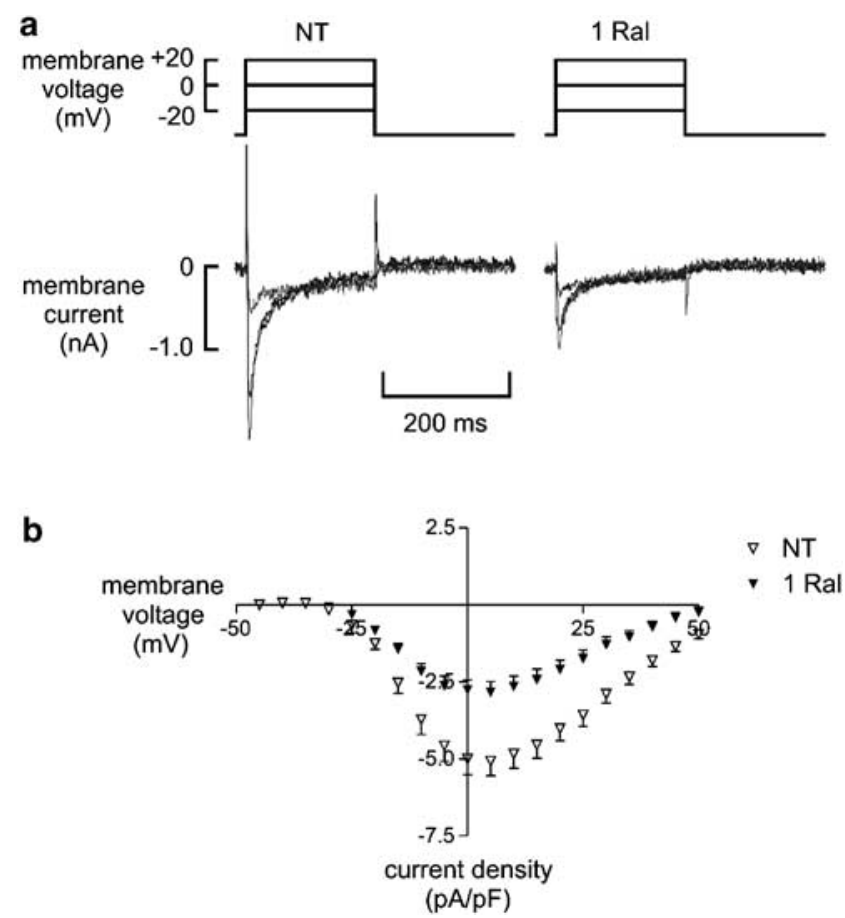

Figure 6 Effects of $1 \mu \mathrm{M}$ raloxifene on the L-type $\mathrm{Ca}^{2+}$ current $\left(\mathrm{I}_{\mathrm{Ca}, \mathrm{L}}\right)$. (a) Sample recordings showing $\mathrm{I}_{\mathrm{Ca}, \mathrm{L}}$ elicited at three depolarising potentials in normal Tyrode (NT) and in the presence of $1 \mu \mathrm{M}$ raloxifene (1 Ral). (b) Current - voltage plot showing the mean peak $\mathrm{I}_{\mathrm{Ca}, \mathrm{L}}$ in NT (open triangle) and Ral (closed triangle) over the whole range of potentials tested $(n=18)$.

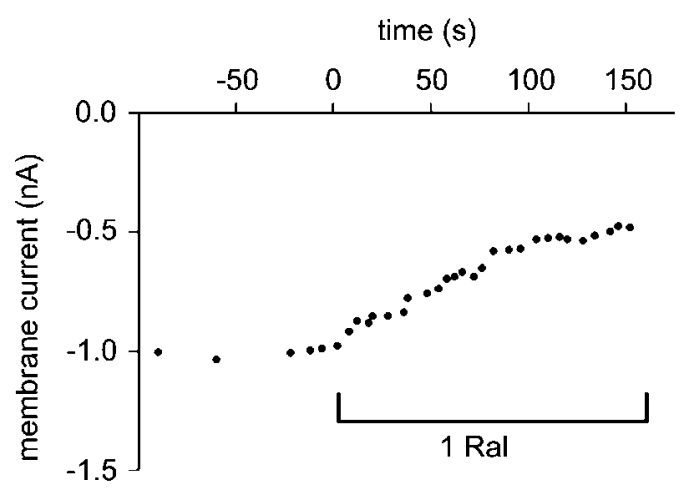

Figure 7 Time course of $\mathrm{Ca}^{2+}$ current inhibition by $1 \mu \mathrm{M}$ raloxifene. Peak L-type $\mathrm{Ca}^{2+}$ current before and after the addition of $1 \mu \mathrm{M}$ raloxifene to the superfusing solution.

was $-8.7 \pm 1.5 \mathrm{mV}$ in NT and $-10.4 \pm 1.7 \mathrm{mV}$ after application of $1 \mu \mathrm{M}$ raloxifene $(P=\mathrm{NS}, n=10)$, while $\mathrm{V}_{50}$ for inactivation was $-20.9 \pm 1.5$ and $-19.2 \pm 1.7 \mathrm{mV}$ respectively $(P=\mathrm{NS})$.

\section{Effects of raloxifene on sarcoplasmic reticulum $\mathrm{Ca}^{2+}$ content}

We next investigated whether raloxifene exerts any additional effects on the sarcoplasmic reticulum $\mathrm{Ca}^{2+}$ load that may contribute to the decrease in cell shortening and $\mathrm{Ca}^{2+}$ transient amplitude. We found that there was no significant difference in the integrals of the $\mathrm{Na}^{+} / \mathrm{Ca}^{2+}$ exchanger currents 


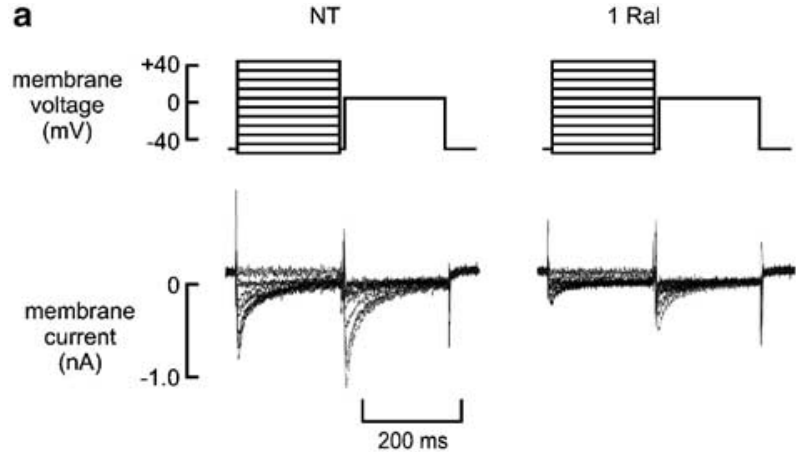

b

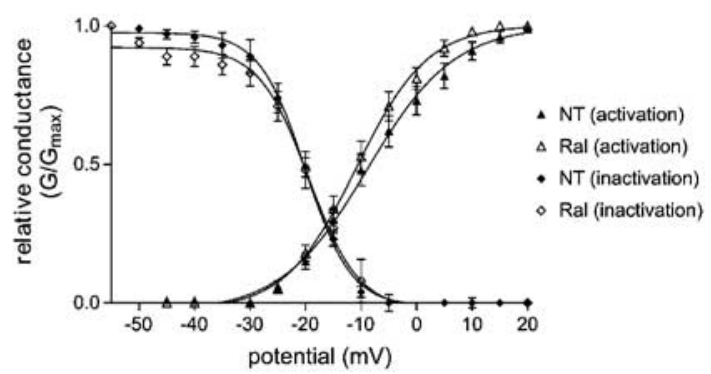

Figure 8 Effects of raloxifene on voltage-dependent activation and inactivation of the L-type $\mathrm{Ca}^{2+}$ current. (a), Sample traces showing currents elicited for calculation of inactivation parameters in normal Tyrode (NT) and after the application of $1 \mu \mathrm{M}$ Raloxifene (1 Ral). Protocol plots are shown in the upper panel. (b) Boltzmann plots of steady-state activation and inactivation parameters.

obtained before compared with those obtained after the addition of $1 \mu \mathrm{M}$ raloxifene $(0.26 \pm 0.02 \mathrm{pC} / \mathrm{pF}$ compared with $0.24 \pm 0.03 \mathrm{pC} / \mathrm{pF}$, respectively, $n=13$ ). Control experiments using two consecutive caffeine releases in NT (rather than a second release in the presence of raloxifene) revealed no significant change in SR $\mathrm{Ca}^{2+}$ load between the caffeine releases (results not shown).

\section{Discussion}

We have demonstrated for the first time that the widely used selective ER modulator, raloxifene, acutely suppresses ventricular myocyte contractility through $\mathrm{Ca}^{2+}$ channel antagonism. This appears to be similar to the known acute actions of the mammalian oestrogen, $17 \beta$-oestradiol, although importantly, the effects of raloxifene described here are observed at much lower concentrations.

The suppression of cell shortening and the $\mathrm{Ca}^{2+}$ transient produced by raloxifene appears to be mediated via the ER as incubation with the specific ER antagonist, ICI 182,780, completely abolished the inhibitory actions. Similarly, raloxifene also appears to reduce diastolic $\mathrm{Ca}^{2+}$ levels through an ER-dependent mechanism. Interactions of selective ER modulators with the ER are extremely complex and involve conformational changes in the ER-ligand structure that are distinct from those produced by $17 \beta$-oestradiol (Brzozowski et al., 1997; Pike et al., 1999; Lonard \& Smith, 2002). It is therefore possible that, although both raloxifene and $17 \beta$ oestradiol both decrease $\mathrm{I}_{\mathrm{Ca}, \mathrm{L}}$ and reduce cardiac contractility, their mechanisms of action differ. The precise pathways linking ER activation with L-type $\mathrm{Ca}^{2+}$ channel activity are currently unknown and warrant further investigation. Although it is also unclear at present whether the acute $\mathrm{Ca}^{2+}$ channel antagonistic actions of $17 \beta$-oestradiol are mediated via the ER, the protective actions of this oestrogen in female ventricular myocytes on hypoxia-reoxygenationinduced $\mathrm{Ca}^{2+}$ loading does appear to be ER-mediated (Jovanovic et al., 2000). ICI 182,780 binds to the classical ER $(\mathrm{ER} \alpha)$ with a similar binding affinity to raloxifene (Wijayaratne et al., 1999) and was used in our study as a competitive inhibitor of any acute ER-mediated actions of raloxifene. Our control experiments with ICI 182,780 alone showed that this compound does not significantly affect myocyte contractility acutely or after a $1 \mathrm{~h}$ incubation period. Although ICI 182,780 has been demonstrated to decrease levels of ER $\alpha$ expression when incubated with cells for $48 \mathrm{~h}$ (Wijayaratne et al., 1999), it is unlikely that this occurred to any significant degree in our experiments with an incubation period of $1 \mathrm{~h}$.

During the mammalian cardiac action potential $\mathrm{Ca}^{2+}$ enters the cell predominantly through L-type $\mathrm{Ca}^{2+}$ channels and triggers further $\mathrm{Ca}^{2+}$ release from $\mathrm{Ca}^{2+}$ stores within the sarcoplasmic reticulum (Bers \& Perez-Reyes, 1999). This process of $\mathrm{Ca}^{2+}$-induced $\mathrm{Ca}^{2+}$-release results in a rapid rise in intracellular free $\mathrm{Ca}^{2+}$ (the $\mathrm{Ca}^{2+}$ transient), culminating in myofilament shortening and cell contraction. A diminished $\mathrm{Ca}^{2+}$ transient amplitude may therefore result from a lower $\mathrm{I}_{\mathrm{Ca}, \mathrm{L}}$ or decreased sarcoplasmic reticulum $\mathrm{Ca}^{2+}$ content or both. The finding that sarcoplasmic reticulum $\mathrm{Ca}^{2+}$ content was unaltered in the presence of raloxifene suggests that inhibition of $\mathrm{I}_{\mathrm{Ca}, \mathrm{L}}$ is the main mechanism by which this compound decreases the $\mathrm{Ca}^{2+}$ transient amplitude and consequently cell shortening. Furthermore, a constant sarcoplasmic reticulum $\mathrm{Ca}^{2+}$ load coupled with reduced $\mathrm{Ca}^{2+}$ influx implies that $\mathrm{Ca}^{2+}$ efflux would also need to decrease in order to maintain steady-state $\mathrm{Ca}^{2+}$ balance in the presence of raloxifene (Eisner et al., 2000).

The profound inhibition of $\mathrm{I}_{\mathrm{Ca}, \mathrm{L}}$ by raloxifene over the range of potentials tested is similar to previously documented direct actions of $17 \beta$-oestradiol on cardiac myocytes (Jiang et al., 1992; Grohe et al., 1996; Nakajima et al., 1999a). However, raloxifene did not significantly shift the steady-state activation or inactivation curves. This contrasts with the known effects of $17 \beta$-oestradiol and dihydropyridine $\mathrm{Ca}^{2+}$ channel antagonists, which produce a leftward shift of the steady-state inactivation curves (Nakajima et al., 1999a, b; Porzig, 1990). Raloxifene therefore does not appear to preferentially exert inhibitory actions on activated or inactivated states of the L-type $\mathrm{Ca}^{2+}$ channel and consequently its mechanism of $\mathrm{Ca}^{2+}$ channel antagonism may be different to that of $17 \beta$-oestradiol.

The length and shape of the cardiac action potential are dependent upon concerted changes in depolarising (primarily $\mathrm{Na}^{+}$and $\mathrm{Ca}^{2+}$ ) and repolarising (mainly $\mathrm{K}^{+}$) currents. In addition, APD is intricately related to sarcoplasmic reticulum $\mathrm{Ca}^{2+}$ content and $\mathrm{Ca}^{2+}$ transient amplitude (Terracciano et al., 1997; Han et al., 2002). Therefore, the shortened APD observed in the presence of raloxifene may solely be a function of $\mathrm{I}_{\mathrm{Ca}, \mathrm{L}}$ inhibition and a decreased $\mathrm{Ca}^{2+}$ transient amplitude. However, effects on repolarising $\mathrm{K}^{+}$currents are also likely, particularly in view of the fact that shortening of the action potential was fully reversible upon washout of raloxifene, 
whereas inhibition of $\mathrm{I}_{\mathrm{Ca}, \mathrm{L}}$ was only partially reversible. Whether raloxifene directly modulates $\mathrm{K}^{+}$currents is not known, although it does appear to reduce myocardial infarct size and the incidence of ventricular fibrillation during reperfusion partly via the opening of $\mathrm{Ca}^{2+}$-activated $\mathrm{K}^{+}$ channels (Ogita et al., 2002).

The observation that raloxifene no longer increased time to peak $\mathrm{Ca}^{2+}$ transient in myocytes that had been incubated with ICI 182,780 suggests that this effect is ER-dependent. Kinetics of the $\mathrm{Ca}^{2+}$ transient during field stimulation are determined by a variety of factors, including changes in ionic fluxes/ membrane potential (both of which are affected by APD) and sarcoplasmic reticular handling of intracellular $\mathrm{Ca}^{2+}$. Consequently, the raloxifene-induced changes in time to peak $\mathrm{Ca}^{2+}$ transient may reflect effects of the compound on membrane
$\mathrm{Ca}^{2+}$ and/or $\mathrm{K}^{+}$currents. It is also possible that raloxifene exerts direct actions on sarcoplasmic reticular $\mathrm{Ca}^{2+} / \mathrm{K}^{+}$ fluxes, although our experiments were not specifically designed to test this. In support of the latter action, however, is the finding that the closely-related compound tamoxifen inhibits movement of $\mathrm{Ca}^{2+}$ out of the sarcoplasmic reticulum in isolated vesicles obtained from rat cardiac myocytes (Kargacin et al., 2000).

In conclusion, the present study provides evidence, at the level of single cardiac myocytes, that raloxifene directly affects cardiac function through $\mathrm{Ca}^{2+}$ channel antagonism. The clinical relevance of this effect remains to be determined.

We thank the British Heart Foundation for financial support.

\section{References}

BERS, D.M. \& PEREZ-REYES, E. (1999). Ca channels in cardiac myocytes: structure and function in $\mathrm{Ca}$ influx and intracellular $\mathrm{Ca}$ release. Cardiovasc.Res., 42, 339-360.

BJARNASON, N.H., HAARBO, J., BYRJALSEN, I., KAUFFMAN, R.F. \& CHRISTIANSEN, C. (1997). Raloxifene inhibits aortic accumulation of cholesterol in ovariectomized, cholesterol-fed rabbits. Circulation, 96, 1964.

BRZOZOWSKI, A.M., PIKE, A.C., DAUTER, Z., HUBbARD, R.E., BONN, T., ENGSTROM, O., OHMAN, L., GREENE, G.L., GUSTAFSSON, J.A. \& CARLQUIST, M. (1997). Molecular basis of agonism and antagonism in the oestrogen receptor. Nature, 389, 753-758.

CLARKSON, T.B., ANTHONY, M.S. \& JEROME, C.P. (1998). Lack of effect of raloxifene on coronary artery atherosclerosis of postmenopausal monkeys. J. Clin. Endocrinol. Metab., 83, 721

DARDES, R.C. \& JORDAN, V.C. (2000). Novel agents to modulate oestrogen action. Br.Med.Bull., 56, 773-786.

DELMAS, P.D., BJARNASON, N.H., MITLAK, B.H., RAVOUX, A.C., SHAH, A.S., HUSTER, W.J., DRAPER, M. \& CHRISTIANSEN, C. (1997). Effects of raloxifene on bone mineral density, serum cholesterol concentrations, and uterine endometrium in postmenopausal women. N. Engl. J. Med., 337, 1641-1647.

EISNER, D.A., CHOI, H.S., DIAZ, M.E., O'NEILL, S.C. \& TRAFFORD, A.W. (2000). Integrative analysis of calcium cycling in cardiac muscle. Circ.Res., 87, 1087-1094.

FIGTREE, G.A., LU, Y., WEBB, C.M. \& COLLINS, P. (1999). Raloxifene acutely relaxes rabbit coronary arteries in vitro by an estrogen receptor-dependent and nitric oxide-dependent mechanism. Circulation, 100, 1095-1101.

GRADY, D., HERRINGTON, D., BITTNER, V., BLUMENTHAL, R., DAVIDSON, M., HLATKY, M., HSIA, J., HULLEY, S., HERD, A., KHAN, S., NEWBY, L.K., WATERS, D., VITTINGHOFF, E. \& WENGER, N. (2002). Cardiovascular disease outcomes during 6.8 years of hormone therapy: heart and Estrogen/progestin Replacement Study follow-up (HERS II). JAMA, 288, 49-57.

GROHE, C., KAHLERT, S., LOBBERT, K., MEYER, R., LINZ, K.W., KARAS, R.H. \& VETTER, H. (1996). Modulation of hypertensive heart disease by estrogen. Steroids, 61, 201-204.

HAN, C., TAVI, P. \& WECKSTROM, M. (2002). Modulation of action potential by $\left[\mathrm{Ca}^{2+}\right] \mathrm{i}$ in modeled rat atrial and guinea pig ventricular myocytes. Am. J. Physiol. Heart Circ. Physiol., 282, H1047.

HAYWARD, C.S., KELLY, R.P. \& COLLINS, P. (2000). The roles of gender, the menopause and hormone replacement on cardiovascular function. Cardiovasc.Res., 46, 28-49.

JIANG, C., POOLE-WILSON, P.A., SARREL, P.M., MOCHIZUKI, S., COLLINS, P. \& MACLEOD, K.T. (1992). Effect of 17 beta-oestradiol on contraction, $\mathrm{Ca}^{2+}$ current and intracellular free $\mathrm{Ca}^{2+}$ in guineapig isolated cardiac myocytes. Br.J.Pharmacol., 106, 739-745.

JOVANOVIC, S., JOVANOVIC, A., SHEN, W.K. \& TERZIC, A. (2000). Low concentrations of 17 beta-estradiol protect single cardiac cells against metabolic stress-induced $\mathrm{Ca}^{2+}$ loading. J. Am. Coll. Cardiol., 36, 948-952.

KARGACIN, M.E., ALI, Z., WARD, C.A., POLlOCK, N.S. \& KARGACIN, G.J. (2000). Tamoxifen inhibits Ca uptake by the cardiac sarcoplasmic reticulum. Pflugers Arch. Eur. J. Physiol., 440, 573-579.

LONARD, D.M. \& SMITH, C.L. (2002). Molecular perspectives on selective estrogen receptor modulators (SERMs): progress in understanding their tissue-specific agonist and antagonist actions. Steroids, 67, 15-24

MACLEOD, K.T. \& HARDING, S.E. (1991). Effects of phorbol ester on contraction, intracellular $\mathrm{pH}$ and intracellular $\mathrm{Ca}^{2+}$ in isolated mammalian ventricular myocytes. J. Physiol., 444, 481-498.

MEYER, R., LINZ, K.W., SURGES, R., MEINARDUS, S., VEES, J., HOFFMANN, A., WINDHOLZ, O. \& GROHE, C. (1998). Rapid modulation of L-type calcium current by acutely applied oestrogens in isolated cardiac myocytes from human, guinea-pig and rat. Exp. Physiol., 83, 305-321.

MOSCA, L., MANSON, J.E., SUTHERLAND, S.E., LANGER, R.D., MANOLIO, T. \& BARRETT-CONNOR, E. (1997). Cardiovascular disease in women : a statement for healthcare professionals from the american heart association. Circulation, 96, 2468-2482.

NAKAJIMA, T., IWASAWA, K., OONUMA, H., MORITA, T., GOTO, A., WANG, Y. \& HAZAMA, H. (1999a). Antiarrhythmic effect and its underlying ionic mechanism of 17 beta-estradiol in cardiac myocytes. Br. J. Pharmacol., 127, 429-440.

NAKAJIMA, T., IWASAWA, K., OONUMA, H., IMUTA, H., HAZAMA, H., ASANO, M., MORITA, T., NAKAMURA, F., SUZUKI, Ji., SUZUKI, S., KAWAKAMI, Y., OMATA, M. \& OKUDA, Y. (1999b). Troglitazone Inhibits voltage-dependent calcium currents in guinea pig cardiac myocytes. Circulation, 99, 2942-2950.

OGITA, H., NODE, K., ASANUMA, H., SANADA, S., LIAO, Y., TAKASHIMA, S., ASAKURA, M., MORI, H., SHINOZAKI, Y., HORI, M. \& KITAKAZE, M. (2002). Amelioration of ischemia- and reperfusion-induced myocardial injury by the selective estrogen receptor modulator, raloxifene, in the canine heart. J. Am. Coll. Cardiol., 40, 998-1005.

PIKE, A.C., BRZOZOWSKI, A.M., HUBBARD, R.E., BONN, T., THORSELL, A.G., ENGSTROM, O., LJUNGGREN, J., GUSTAFSSON, J.A. \& CARLQUIST, M. (1999). Structure of the ligand-binding domain of oestrogen receptor beta in the presence of a partial agonist and a full antagonist. EMBO J., 18, $4608-4618$.

PORZIG, H. (1990). Pharmacological modulation of voltage-dependent calcium channels in intact cells. Rev. Physiol. Biochem. Pharmacol. 114, 209-262.

RIGGS, B.L. \& HARTMANN, L.C. (2003). Selective estrogen-receptor modulators - mechanisms of action and application to clinical practice. N. Engl. J. Med., 348, 618-629.

SIMONCINI, T., GENAZZANI, A.R. \& LIAO, J.K. (2002). Nongenomic mechanisms of endothelial nitric oxide synthase activation by the selective estrogen receptor modulator raloxifene. Circulation, $\mathbf{1 0 5}$, $1368-1373$. 
SPURGEON, H.A., STERN, M.D., BAARTZ, G., RAFFAELI, S., HANSFORD, R.G., TALO, A., LAKATTA, E.G. \& CAPOGROSSI, M.C. (1990). Simultaneous measurement of $\mathrm{Ca}^{2+}$, contraction, and potential in cardiac myocytes. Am.J.Physiol., 258, H574-H586.

TERRACCIANO, C.M., TWEEDIE, D. \& MACLEOD, K.T. (1997). The effects of changes to action potential duration on the calcium content of the sarcoplasmic reticulum in isolated guinea-pig ventricular myocytes. Pflugers Arch., 433, 542-544.

VARRO, A., NEGRETTI, N., HESTER, S.B. \& EISNER, D.A. (1993). An estimate of the calcium content of the sarcoplasmic reticulum in rat ventricular myocytes. Pflugers Arch., 423, 158-160.

WALSH, B.W., KULLER, L.H., WILD, R.A., PAUL, S., FARMER, M., LAWRENCE, J.B., SHAH, A.S. \& ANDERSON, P.W. (1998). Effects of raloxifene on serum lipids and coagulation factors in healthy postmenopausal women. JAMA, 279, 1445-1451.

WASSMANN, S., LAUFS, U., STAMENKOVIC, D., LINZ, W., STASCH, J.P., AHLBORY, K., ROSEN, R., BOHM, M. \& NICKENIG, G. (2002). Raloxifene improves endothelial dysfunction in hypertension by reduced oxidative stress and enhanced nitric oxide production. Circulation, 105, 2083-2091.
WENGER, N.K., SPEROFF, L. \& PACKARD, B. (1993). Cardiovascular health and disease in women. N. Engl. J. Med., 329, 247-256.

WiJAYARATNe, A.L., NAGEL, S.C., PAIGE, L.A., CHRISTENSEN, D.J., NORRIS, J.D., FOWLKES, D.M. \& MCDONNELL, D.P. (1999). Comparative analyses of mechanistic differences among antiestrogens. Endocrinology, 140, 5828-5840.

ZHAI, P., EURELL, T.E., COTTHAUS, R., JEFFERY, E.H., BAHR, J.M. \& GROSS, D.R. (2000). Effect of estrogen on global myocardial ischemia-reperfusion injury in female rats. Am. J. Physiol. Heart Circ. Physiol., 279, H2766-H2775.

(Received October 7, 2003

Revised January 5, 2004 Accepted February 11, 2004) 